\title{
PENINGKATAN HASIL BELAJAR MATEMATIKA MATERI PROGRAM LINIER MELALUI PENERAPAN MODEL PEMBELAJARAN DISCOVERY LEARNING BERBANTUAN APLIKASI GEOGEBRA VERSI ANDROID
}

\author{
Heri Risdianto \\ SMA Negeri 3 Langsa, Aceh \\ Email: hrisdianto@gmail.com
}

\begin{abstract}
ABSTRAK
Penelitian ini bertujuan untuk meningkatkan pemahaman siswa tentang konsep Program Linier, dengan subjek penelitian siswa kelas XI IPA 2 SMA Negeri 3 Langsa Tahun Pelajaran 2019/2020. Pendekatan yang dilakukan dalam penelitian ini adalah pendekatan kualitatif dengan menggunakan desain penelitian tindakan kelas. Tindakan dilakukan dalam dua siklus, siklus pertama implementasi materi pembelajaran program linier dengan Model Pembelajaran Penemuan berbantuan aplikasi Geogebra Versi Android yang dipraktikkan oleh guru, dan siklus kedua implementasi materi pembelajaran Program Linier dengan Model Pembelajaran penemuan terbimbing berbantuan aplikasi Geogebra Versi Android yang dipraktekkan oleh siswa. Data dalam penelitian ini diperoleh dengan cara observasi, angket, dan tes terhadap objek penelitian. Data yang diperoleh dari observasi dan angket dianalisis dengan analisis kualitatif, sedangkan data yang diperoleh dari tes dianalisis dengan analisis kuantitatif. Hasil penelitian menunjukkan bahwa ketuntasan siswa pada materi program linier $>85 \%$ dengan rata-rata hasil tes akhir 83,6.
\end{abstract}

Kata Kunci: Peningkatan hasil belajar matematika, Penelitian Tindakan Kelas, Pembelajaran Penemuan terbimbing, Aplikasi Geogebra versi android

\section{PENDAhuluan}

Belajar pada hakekatnya adalah proses interaksi antara siswa dengan lingkungannya, sehingga terjadi perubahan perilaku menjadi lebih baik (Mulyasa, 2002: 100). Dalam pembelajaran, tugas terpenting guru adalah mengkondisikan lingkungan sehingga mendukung perubahan perilaku

Pelaksanaan KTSP sebenarnya menuntut terciptanya iklim pendidikan yang memungkinkan tumbuhnya semangat intelektual dan keilmuan bagi setiap guru, mulai dari rumah, di sekolah, dan di masyarakat. Hal ini berkaitan dengan pergeseran peran guru yang semula lebih sebagai pengajar dan sekarang menjadi fasilitator pembelajaran

Namun pada kenyataannya siswa seringkali menjadi korban dan dianggap sebagai sumber kesulitan belajar. Padahal kesulitan tersebut mungkin berasal dari luar diri siswa itu sendiri, misalnya proses pembelajaran yang berkaitan dengan kurikulum, cara penyajian materi pelajaran, dan model pembelajaran yang dilakukan oleh guru. Hal ini dapat mengakibatkan kemampuan matematis serta sikap siswa terhadap matematika cukup memprihatinkan. Ada yang takut, ada yang bosan dan ada yang alergi matematika. Akibatnya siswa tidak mampu mandiri dan tidak tahu harus berbuat apa sehingga kemampuan matematis siswa sangat rendah kualitasnya

Pembelajaran matematika menurut Russeffendi (1993:109) adalah kegiatan belajar mengajar yang sengaja dilakukan untuk memperoleh pengetahuan dengan memanipulasi simbol-simbol dalam matematika sehingga menimbulkan perubahan perilaku.

Dalam kurikulum 2013 disebutkan bahwa pembelajaran matematika adalah pembelajaran yang bertujuan:

1. Melatih cara berpikir dan menalar dalam menarik kesimpulan, misalnya melalui kegiatan inkuiri, eksplorasi, eksperimentasi, menunjukkan persamaan, perbedaan, konsistensi dan inkonsistensi

2. Mengembangkan aktivitas kreatif yang melibatkan imajinasi, intuisi, dan penemuan dengan mengembangkan pemikiran divergen, 
orisinal, rasa ingin tahu, membuat prediksi dan tebakan, serta bereksperimen

3. Mengembangkan keterampilan pemecahan masalah

4. Mengembangkan kemampuan menyampaikan informasi atau mengkomunikasikan gagasan antara lain melalui percakapan lisan, grafik, peta, diagram dalam menjelaskan gagasan

Berdasarkan pengalaman saya mengajar di SMAN 3 Langsa, siswa sering mengalami kesulitan dalam belajar matematika khususnya program linier. Program linier merupakan salah satu materi pelajaran yang dianggap sulit dipahami siswa karena metode pembelajaran yang digunakan guru masih konvensional

Permasalahan kurangnya kemampuan pemecahan masalah matematis dapat dilihat dari contoh soal dalam menyelesaikan soal cerita program linier berikut ini: Seorang anak setelah lulus SMA akan berwiraswasta dengan berjualan kue. Anak tersebut memiliki modal Rp145.000 dan memiliki keranjang yang dapat menampung 400 kue. Anak tersebut membeli tempe seharga Rp250,- dijual seharga Rp300,- dan membeli tahu seharga Rp400,- dan dijual Rp500,-. Berapa keuntungan maksimal yang bisa didapat anak?

Ternyata sebagian besar siswa mengalami kesulitan dalam menyelesaikan soal dan meminta temannya untuk menyelesaikan soal tersebut serta menunjukkan rasa kurang percaya diri dalam menyelesaikannya. Namun jika siswa tersebut diberikan sedikit bantuan dan dukungan, ternyata sebagian besar siswa dapat menyelesaikannya

Menyadari keadaan tersebut, menggali dan mengembangkan kemampuan pemecahan masalah matematis siswa perlu mendapat perhatian guru dalam pembelajaran matematika. Siswa harus memiliki kesempatan yang cukup untuk menggunakan kemampuan pemecahan masalah matematisnya, berlatih, merumuskan, terlibat dalam memecahkan masalah yang kompleks yang memerlukan upaya yang sangat besar dan kemudian didorong untuk merefleksikan pemikirannya.

Paradigma baru dalam pembelajaran membuka peluang untuk menggunakan dan mengembangkan berbagai model yang berorientasi pada pengembangan kemampuan dan keterampilan berpikir siswa. Ausubel (Ruseffendi, 2006) pembelajaran harus menekankan keterlibatan aktif siswa dalam memahami konsep atau prinsip matematika untuk memungkinkan pembelajaran yang bermakna, siswa tidak hanya belajar untuk mengetahui sesuatu (learning to know about), tetapi belajar untuk melakukan, belajar menjadi dan belajar bagaimana belajar dan cara bersosialisasi (learning to live together). Kemungkinan beragamnya respon/tindakan yang diberikan siswa terhadap masalah yang dihadapinya dan tidak sesuai dengan prediksi guru, merupakan hal yang wajar dan tidak boleh dianggap sebagai masalah. Menurut Suryadi (2008) meskipun masih terdapat respon siswa yang tidak sesuai dengan prediksi guru, namun teknik scaffolding yang digunakan guru mampu mengubah situasi didaktis yang ada sehingga proses berpikir siswa menjadi lebih terarah.

Dari faktor masalah yang dijelaskan oleh Depdiknas (2002) pembelajaran yang berpusat pada guru, kreativitas siswa tidak berkembang secara maksimal, siswa mudah melupakan ilmu yang telah diajarkan, sikap dan aktivitas siswa terhadap pembelajaran yang tidak positif, seperti acuh tak acuh, sikap tidak serius, dan pembelajaran matematika tidak membosankan. Oleh karena itu perlu diupayakan pembelajaran yang dapat menimbulkan aktivitas ilmiah siswa lebih terjaga, pembelajaran yang dapat mengembangkan kreativitas siswa secara maksimal, pembelajaran dimana guru dapat belajar bersama dengan siswa, pembelajaran yang memberikan keleluasaan untuk menggali ilmu secara mandiri, pembelajaran yang melatih siswa dalam membuat kesimpulan. Sehingga pengetahuan dapat tertanam dalam diri siswa secara mendalam, tidak mudah dilupakan. Pembelajaran yang sesuai dengan situasi didaktis, karakteristik dan fakta di lapangan adalah pembelajaran dengan model penemuan terbimbing.

Pembelajaran dengan model penemuan terbimbing merupakan model pembelajaran yang bertujuan untuk memberikan jalan kepada siswa untuk membangun keterampilan intelektual (thinking skills) yang berkaitan dengan proses berpikir reflektif. Jika berpikir adalah tujuan utama pendidikan, maka harus ditemukan cara untuk membantu individu membangun kemampuan tersebut (Sanjaya, 2008). Artinya dalam penelitian ini siswa diharapkan mampu mengomunikasikan hal-hal yang telah dipahami dan yang ada dalam pikirannya untuk 
membangun suatu pengetahuan yang akan diperoleh siswa.

Langkah-langkah dalam model pembelajaran penemuan terbimbing adalah, siswa dihadapkan pada suatu masalah, siswa mengajukan asumsi/hipotesis, siswa mengumpulkan data, siswa menguji hipotesis, dan siswa membentuk kesimpulan. Maka untuk memudahkan langkahlangkah tersebut dalam pembelajaran ini siswa harus mampu memahami masalah, kemudian memikirkan bagaimana mereka memberi atau membuat tebakan sementara tentang suatu gejala atau situasi. Kemudian siswa dalam mengumpulkan data, melakukan observasi dan investigasi untuk memberikan jawaban atas dugaan yang telah dirumuskan.

Ketika siswa dilibatkan dalam mengamati, diharapkan akan muncul pemahaman yang mendalam di benak siswa, dilanjutkan dengan melakukan kegiatan untuk membuktikan dugaan yang diberikan. Kegiatan penemuan terbimbing kemudian dilanjutkan dengan mendorong siswa untuk melakukan diskusi sebagai bentuk komunikasi, baik lisan maupun tulisan untuk menyempurnakan bukti yang telah mereka lakukan, dan kegiatan siswa untuk mencoba meyakinkan siswa lain tentang ide-ide matematika yang mereka yakini. mengungkap bukti yang dapat diterima pikirannya. Sehingga melalui pembelajaran dengan model penemuan terbimbing ini diharapkan dapat meningkatkan kemampuan pemecahan masalah matematis siswa.

Joyce dan Well (1992) mengemukakan bahwa model pembelajaran penemuan terbimbing terdiri dari lima fase, yaitu:

1. Konfrontasi dengan Masalah: Fase dimana siswa diharapkan memiliki masalah yang harus diselesaikan.

2. Data Gathering-Verification: Fase dimana siswa mengumpulkan data dari informasi yang mereka amati.

3. Data Gathering-Experimentation: Fase dimana siswa mengumpulkan data hasil eksperimen.

4. Organizing-Formidating Explanation: Fase dimana siswa mengorganisasikan data dan penjelasan.

5. Analisis Proses Inkuiri: Fase di mana siswa menganalisis proses temuan mereka
Karena model pembelajaran penemuan terbimbing mengandung tahapan pengamatan yang mengarah pada pemahaman suatu konsep, pembelajaran harus dibuat menarik bagi siswa, sehingga siswa penasaran dan mau melakukan pengamatan. Dalam hal ini guru perlu mengarahkan siswa untuk dapat mengamati masalah dengan mengajukan pertanyaan yang dapat mengarah pada konsep yang diinginkan. Karena observasi diarahkan pada suatu konsep, mungkin timbul hal-hal yang harus diketahui siswa, tetapi siswa belum mengetahuinya. Untuk itu siswa akan berusaha mencari tahu dengan bertanya kepada sesama siswa. guru, atau sumber lain. Setelah hal-hal yang ingin diketahui terkumpul, untuk menuju suatu konsep siswa perlu mengajukan tebakan kemudian mengujinya dengan menganalisis berdasarkan data yang ada untuk menemukan sesuatu..

Tujuan utama pembelajaran penemuan terbimbing adalah untuk membantu siswa mengembangkan intelektual dan keterampilan lainnya, seperti mengajukan pertanyaan dan menemukan atau mencari jawaban yang berasal dari rasa ingin tahu siswa.

Namun pembelajaran penemuan terbimbing saja tidak cukup, karena untuk menyelesaikan materi program linier siswa tidak hanya harus mampu memodelkan masalah tetapi harus memiliki kemampuan melukiskan luasan penyelesaian sistem pertidaksamaan linier dan menentukan titik potong dua garis. Jika kita membuatnya secara manual akan membutuhkan waktu yang lama untuk menyelesaikan materi ini.

Untuk mendukung pembelajaran ini, digunakan TIK, TIK dianggap sebagai alat penting untuk mengembangkan pemahaman tentang konsep matematika. Tantangan bagi guru adalah menggunakan TIK dalam berbagai cara yang mendorong pemikiran matematis dan pengembangan konsep siswa (Rani \& Anisha, 2017)

Kemajuan fenomenal dalam teknologi seluler dan ledakan yang menyertainya dalam ketersediaan Aplikasi seluler telah memengaruhi hampir semua aspek kehidupan kita, dan diperkirakan akan berdampak lebih luas dan lebih dalam dalam waktu dekat. Aplikasi baru mulai membuat terobosan dalam domain pendidikan. Karena sebagian besar siswa bergulat dengan 
konsep Matematika/ Teknik yang abstrak dan kompleks,

Aplikasi yang dirancang dengan baik untuk mempelajari konsep Matematika/ Teknik akan bertindak sebagai suplemen yang kuat untuk pengajaran dan pembelajaran tradisional, dan akan sangat bermanfaat bagi siswa dan pelajar (Subramanya \& Farahani, 2012 )

Lebih khusus TIK yang digunakan adalah Software Geogebra versi Android, karena selain aplikasi gratis, semua siswa Kelas XI IPA 2 memiliki Android

\section{METODE}

Jenis penelitian ini adalah penelitian tindakan kelas. Hal ini sesuai dengan pendapat Ebbutt dalam (Wiriaatmadja, 2005) yang mengatakan bahwa penelitian tindakan adalah studi sistematis tentang upaya untuk meningkatkan pelaksanaan praktik pendidikan oleh sekelompok guru dengan melakukan tindakan dalam pembelajaran, berdasarkan refleksi mereka pada hasil penelitian tersebut. tindakan

Penelitian tindakan kelas ini dilaksanakan melalui dua siklus. Setiap siklus terdiri dari 4 (empat) tahap yaitu: perencanaan tindakan, pelaksanaan tindakan, observasi/evaluasi, dan refleksi. Adapun tahapan tahapan implementasi pada setiap siklus perancangan model PTK Kurt Lewin dapat dilihat pada Gambar di bawah ini

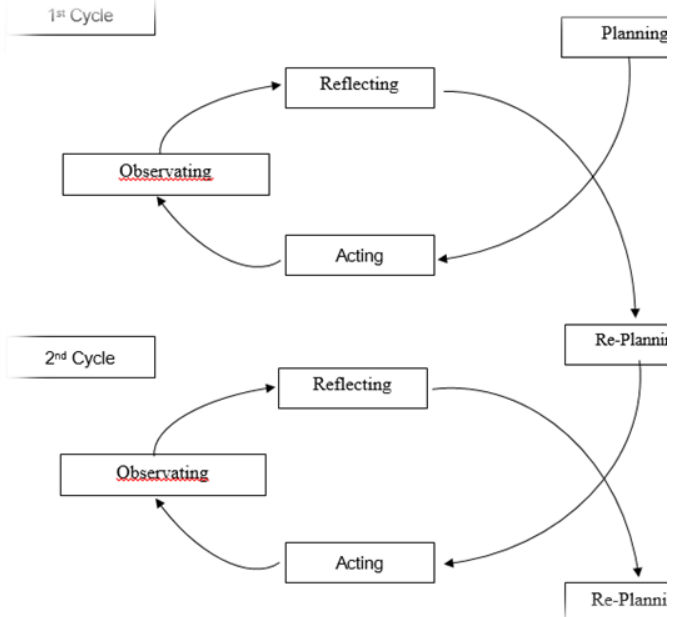

Gambar 1. Desain model penelitian tindakan kelas Kurt Lewin's

Siklus I akan dilaksanakan dalam tiga kali pertemuan. Adapun pertemuan pertama dan kedua merupakan pelaksanaan pembelajaran dengan model guided discovery learning assist oleh Software Geogebra Versi Android, dan tes untuk memperoleh informasi setelah pembelajaran berlangsung, sedangkan pertemuan ketiga merupakan akhir siklus persiapan tes disesuaikan dengan kisi-kisi tes. yang telah dibuat berdasarkan materi yang telah diajarkan pada pertemuan pertama dan kedua.

Perencanaan siklus II disesuaikan dengan hasil refleksi yang diperoleh pada siklus I. Perencanaan direncanakan melibatkan guru senior di sekolah agar hasil penelitian sesuai dengan yang diharapkan.

Subjek penelitian ini adalah siswa kelas XI IPA 2 SMA Negeri 3 Langsa tahun pelajaran 2019/2020 yang berjumlah 32 siswa yang terdiri dari 15 laki-laki dan 17 perempuan. Dan objek penelitian adalah peningkatan hasil belajar Matematika secara linier. materi program untuk siswa kelas XI IPA 2 Tahun Pelajaran 2019/2020 setelah penggunaan model pembelajaran penemuan terbimbing berbantuan software Geogebra versi android.

Metode yang digunakan untuk mengumpulkan data hasil belajar siswa adalah metode tes. Bentuk tes yang digunakan dalam penelitian ini adalah bentuk tes objektif dengan tipe essay. Tes objektif dipilih karena tes objektif memiliki sifat yang lebih representatif dalam hal mencakup dan mewakili materi yang telah diajarkan kepada siswa. Dalam penelitian ini untuk mengukur hasil belajar siswa pada ranah kognitif.

Pendekatan yang digunakan dalam penelitian ini adalah pendekatan kualitatif karena penelitian ini sesuai dengan karakteristik penelitian kualitatif (Sudjana, 2004), yaitu: (a) menggunakan lingkungan alam sebagai sumber data langsung, (b) bersifat deskriptif analitik. , (c) tekanan penelitian pada proses bukan pada hasil, (d) induktif, (e) mengutamakan makna. Lebih lanjut Sudjana (2004) mengatakan bahwa penelitian kualitatif tidak dimulai dari teori-teori yang telah disusun sebelumnya, tetapi dimulai dari lapangan yang berbasis pada lingkungan alam. Data dan informasi di lapangan ditarik ke dalam makna dan konsep, melalui paparan deskriptif analitik, tanpa menggunakan enumerasi dan statistik, karena mengutamakan proses terjadinya peristiwa dan perilaku dalam situasi alamiah. Generalisasi tidak perlu dilakukan karena deskripsi dan interpretasi terjadi dalam konteks ruang, waktu dan situasi tertentu. Pendekatan kualitatif dalam penelitian ini 
digunakan untuk menggali dan mendapatkan gambaran yang jelas tentang situasi kelas dan perilaku siswa selama proses pembelajaran.

\section{HASIL DAN PEMBAHASAN}

Hasil pelaksanaan siklus ke-1 dan ke-2 untuk peningkatan hasil belajar matematika siswa kelas XI IPA 2 SMA Negeri 3 Langsa adalah sebagai berikut:

\subsection{Refleksi Siklus 1}

Pertemuan ke-1

1. Saat membahas luas penyelesaian pertidaksamaan linier masih banyak siswa yang menganggap luas penyelesaian hanya dua titik

2. Banyak siswa yang tidak dapat membedakan luasan yang lebih kecil dan luas dari penyelesaian pertidaksamaan linier

3. Beberapa siswa lupa menentukan penyelesaian persamaan linear sehingga tidak dapat menentukan perpotongan dua garis.

Pertemuan ke-2

1. Saat guru memberikan kesempatan kepada siswa untuk menyampaikan kesulitan yang dialami siswa dalam mengerjakan pekerjaan rumah, hampir semua siswa tidak pernah menyampaikan kesulitannya. Ini karena semua pekerjaan rumah yang mereka lakukan bersama sepulang sekolah, mereka pelajari dari teman-teman mereka yang telah selesai mengerjakannya.

2. Pemahaman siswa tentang luas permukiman masih terbatas pada titik potong antara kedua garis tersebut

Pertemuan ke-3

1. Siswa mengerjakan soal tes akhir siklus ke-1 dengan tertib.

Hasil belajar yang diperoleh siswa pada siklus ke1 ini adalah sebagai berikut:

Tabel 1. Ringkasan hasil tes siklus ke-1

\begin{tabular}{ll}
\hline Tuntas & 9 \\
Tidak Tuntas & 23 \\
Nilai Tertinggi & 80 \\
Nilai Terendah & 30 \\
Rata-rata & 58,28 \\
Jangkauan & 50 \\
\hline
\end{tabular}

Dari tabel di atas dapat dilihat bahwa jumlah siswa yang tuntas secara klasikal hanya $28 \%$ dengan rata-rata 58,28 walaupun ada siswa yang memperoleh nilai 80 .

\subsection{Refleksi Siklus ke-2}

Berdasarkan temuan data selama tindakan, dapat diambil pembahasan berikut ini:

1. Pada awal pembelajaran, tingkat berpikir siswa masih sebatas menentukan penyelesaian pertidaksamaan linier. Tampaknya hanya ada dua siswa yang menunjukkan luas penyelesaian pertidaksamaan linier ketika menjawab pertanyaan guru "Jika diberi garis persamaannya diubah menjadi lebih kecil atau lebih besar bagaimana solusinya?", Sedangkan yang lain hanya menjawab solusinya adalah perpotongan sumbu $\mathrm{x}$ dan sumbu y. Jadi untuk menunjukkan penyelesaiannya, guru dapat menguji beberapa titik di sekitar garis

2. Banyak siswa yang tidak memahami luas penyelesaian sistem pertidaksamaan linier "Bagaimana luas penyelesaian sistem pertidaksamaan linier ?, apakah luas bersih atau luas lainnya?" tidak ada siswa yang menjawab. Hal ini dapat dijelaskan kepada siswa bahwa luas penyelesaian sistem pertidaksamaan linier adalah semua titik yang memenuhi pertidaksamaan linier.

3. Persepsi bahwa penyelesaian sistem pertidaksamaan linier hanyalah titik potong garis dapat dijelaskan dengan cara siswa menguji sendiri beberapa titik di dalam dan di luar daerah pemukiman. Yang mana yang memenuhi, itulah solusi dari sistem pertidaksamaan linier

4. Untuk memperjelas daerah pemukiman dapat dibantu dengan Software Geogebra Versi Android, sehingga siswa tidak terlalu banyak menggambar.

5. Pada awalnya siswa merasa kesulitan untuk membuat model matematika dari masalah program linier. Namun karena model pembelajaran yang digunakan adalah penemuan terbimbing, maka siswa tidak mengalami kesulitan lagi.

Hasil belajar yang diperoleh siswa pada siklus ke-2 adalah sebagai berikut: 
Tabel 2 Ringkasan hasil tes siklus ke-2

\begin{tabular}{ll}
\hline Tuntas & 27 \\
Tidak Tuntas & 5 \\
Nilai Tertinggi & 100 \\
Nilai Terendah & 65 \\
Rata-rata & 83,59375 \\
Jangkauan & 35 \\
\hline Dari tabel di atas dapat dilihat bahwa jumlah \\
siswa yang tuntas secara klasikal sudah mencapai \\
84,32\% dengan rata-rata 83,59. Bahkan ada siswa \\
yang memperoleh nilai 100.
\end{tabular}

\section{KESIMPULAN}

Dari hasil penelitian yang telah dilakukan, dapat diambil kesimpulan sebagai berikut:

1. Penggunaan model pembelajaran penemuan terbimbing berbantuan software Geogebra versi Android meningkatkan kemampuan pemecahan masalah siswa pada materi program linier.

2. Dari hasil tes akhir ketuntasan siswa terhadap materi Program Linier setelah sikluske-2 $>80 \%$ dengan rata-rata hasil tes akhir 83,6.

\section{Daftar Pustaka}

Idris, S. (2015). Peningkatan Hasil Belajar Program Linear Melalui Strategi Pembelajaran Inkuiri Dan Geogebra Siswa Kelas XII IPA1 SMA N 1 Tompobulu. Indonesian Digital Journal of Mathematics and Education, 144 153.

Jelatu, S. (2018). Effect of GeoGebra-Aided REACT Strategy on Understanding of Geometry Concepts. International journal of instruction, 11(4), 325-336.
Joice, B., Weil, M., \& Calhoun, W. (1992). Models of Teaching. Jakarta: Pustaka Pelajar.

Mulyasa, E. (2002). Kurikulum Berbasis Kompetensi, Konsep Karakteristik dan Implementasi. Bandung: Rosdakarya.

Rani, R., \& Anisha. (2017). Role Of ICT To Enhance Mathematics Teaching And To Raising Educational Standards. International Journal of Scientific Research, 488-490.

Russeffendi. (2006). Pengantar kepada Membantu Guru Mengembangkan Kompetensinya dalam Pengajaran Matematika . Bandung: Tarsito.

Sabandar, J. (2007). Berfikir Reflektif. Bandung: Unpublisher.

Subramanya, S., \& Farahani, A. (2012). Design of Smartphone App for Learning Concepts in Mathematics and Rngineering. International Journal of Innovation Science, 173-183.

Sudjana, N. (2004). Penelitian dan Penilaian Pendidikan. Bandung: Sinar Baru Algensindo.

Suharsimi, A. (2006). Penelitian Tindakan Kelas. Jakarta: Bumi Aksara.

Suryadi, D. (2000). Peningkatan Kemampuan Pemecahan Masalah Matematika Siswa SLTP melalui Penerapan Diskusi Kelompok. Bandung: UPI.

Wiriaatmaja, R. (2005). Metode Penelitian Tindakan Kelas. Bandung: Remaja Rosadakarya. 